\author{
새우 통발의 침지시간에 따른 어획 특성 \\ 배봉성* · 안희 춘 - 박성욱 · 박해훈 - 전영 열 \\ 국립수산과학원 동해수산연구소 자원환경과, ${ }^{1}$ 국립수산과학원 수산공학과
}

\title{
Catch characteristics of shrimp trap by submerged time
}

\author{
Bong-Seong BAE*, Heui-Chun AN, Seong-Wook PARK' ${ }^{1}$ Hae-Hoon PARK \\ and Young-Yull CHuN \\ Fisheries Resources and Environment Division, East Sea Fisheries Research Institute, National \\ Fisheries Research \& Development Institute, Gangneung 210-861, Korea \\ ${ }^{1}$ Fisheries Engineering Division, National Fisheries Research \& Development Institute,
} Busan 619-902, Korea

\begin{abstract}
Cast fishing gear needs some time for fishing progress, and catches and their composition by submerged time can change by several cause. Therefore, it is very importance to study fishing capacity of fishing gear by submerged time. This study is to investigate catches and their composition of shrimp trap, that is used in the coastal of the East Sea, and to find the fittest lifting time of trap. Experimental term are September 2006 and August 2007, the location is the coastal of Oho, Goseong, Gangwondo, Korea and one hundred trap is used at each casting and lifting of gear. For convenience of description, survey of 2006 and 2007 are denoted as experimental code 1 and 2, and submerged time 21hr, 43hr and 66hr are denoted as code A, B and C. The result of obtained from the above approach are summarized as follows: Many Northern shrimps(Pandalus eous), dominated 96.36\%, are only catched in experimental code A, and in code B and C, some of coonstripe shrimp(Pandalus hypsinotus) and few morotoge shrimp(Pandalopsis japonica) are catched. CPUE of code 1A, 1B and 1C per trap were 21.67g, 29.51g and 28.48g, and those of code 2A, 2B and 2C per trap were 25.44g, 32.93g and 33.36g. Therefore, 24.66\% of catch increased according as submerged time passes from 1 day to 2 days, and almost no change of catch was to be $-1.1 \%$. Carapace length of code $1 \mathrm{~A}, 1 \mathrm{~B}$ and $1 \mathrm{C}$ were $23.77 \mathrm{~mm}, 25.00 \mathrm{~mm}$ and $25.57 \mathrm{~mm}$, and those of code 2A, 2B and 2C per trap were $23.83 \mathrm{~mm}, 24.95 \mathrm{~mm}$ and $25.45 \mathrm{~mm}$. Thus, the more submerged time is, the less catch of small fish is and the more catch of large fish is. Consequently, fit lifting time of shrimp trap is after 2 days, and if considered trouble of fishing gear and condition of catch, the fittest lifting time is the third successive day of casting date.
\end{abstract}

Keywords: Shrimp trap, Submerged time, Fishing capacity

*Corresponding author: asako@nfrdi.go.kr, Tel: 82-33-660-8523, Fax: 82-33-661-8513 


\section{서 론}

통발을 비롯하여 어 구는 수중에 투입된 후, 어 획 과정 에 일 정한 시간이 필 요하며 어 장 특성, 대 상 자원의 특성, 미끼의 호과 등, 여러 가지 요인 으로 인하여 침지시간에 따른 어획량 및 어획물 의 조성이 항상 달라질 수 있다. 즉 어 구가 자원 에 미치는 영향이 달라진다. 따라서 어 구의 침지 시간에 따라 어구의 어획성 능이 달라지므로 어 구의 침지시간에 따른 어 구의 어획성 능에 대한 연 구가 매우 중요하다.

일 반적으로 침지시간의 증가에 따라 어획량 도 증가할 것으로 생각되지만 여러 가지 연구를 통하여 그렇지 않다는 것이 밝혀젔다(Ogura et al., 1980; Egger, 1982; Chen et al., 1998). 통 발의 경우 투망 후 미끼의 효과가 유지되는 시간 내 에서는 침지시간이 경 과함에 따라 어획량은 증 가하지만 CPUE는 점점 감소하며(Jeong et al., 2002), 그물을 빠져나갈 수 있는 소형어는 일정 시간이 지난 후 미끼의 호과가 사라지면 빠져 나잘 수 있기 때문에, 자원관리를 위해서는 적 정 침지시간이 지난 후에 양망하는 것이 필요하 다. 따라서 이와 관련하여 An and Park(2005; 2006) 와 Chang et al.(2008a; 2008b)은 미끼의 종 류에 따른 어획변화에 대한 연구를 수행한 바 있고, Honda and Fujita(2005)는 자망에 대하여, Kim et al.(2009)은 채뉶기에 대하여 어 구의 침 지시간에 따른 어획변화에 대한 연 구를 수행하 였다. 그러나Jeong et al.(2002)이 플라스틱 붕장 어 통발에 대하여 침지시간에 따른 어획변화를 연구한 바는 있으나 동해안에서 주로 사용되고 있는 스프링식 장구형 새우 통발에 대한 관련 연구는 없다.

따라서 본 연구에서는 동해안에서 가장 보편 적으로 사용되는 새우 통발에 대하여 침지시간 에 따라 어획량 및 어획물의 조성이 어 떻게 달라 지는가를 조사하고 가장 적합한 양망시 점을 알 아보고자 하였다.

\section{재료 및 방법}

\section{시험어구}

새우 통발의 침지시간에 따른 어획량 및 어종 별 크기 조성을 분석하기 위하여 어 획시 험에 사 용된 어구는 Fig. 1 과 같다. 우리나라에서 새우 를 포획하기 위해 사용되 는 통발은 다양한 형태 가 있지만 동해안에서는 문어나 물레고둥 등을 어 획하기 위하여 사용하는 스프링식 장구형 통 발과 동일한 통발을 주로 사용한다. 따라서 본 연 구에서는 시 험해 역에 서 보편적으로 사용하고 있는 통발과 동일한 것을 사용하였으며 그 주요 규격은 다음과 같다. 통 발의 길이는 $740 \mathrm{~mm}$, 양 측면의 직경은 $440 \mathrm{~mm}$ 이고 통발의 형태를 이루 는 철사로 된 테의 굵기는 $6 \mathrm{~mm}$ 이며 비닐피복이 덮여져 있다. 통발 깔때기 입구의 직경은 $440 \mathrm{~mm}$, 안쪽으로 들어간 길이는 $250 \mathrm{~mm}$, 끝의 직경은 $125 \mathrm{~mm}$ 이고 그물감의 재질과 규격은 NYTd210 20ply, mesh. 35mm 이며 그물감의 색상 은 검 정색이다. 시험어 장에 서의 통발어 구의 구 성과 배치 를 Fig. 2 에 나타내었다. 어구의 구성 은 모릿 줄(PPdia. $12 \mathrm{~mm}, 700 \mathrm{~m})$ 에 약 $7 \mathrm{~m}$ 간격 으로 아 릿줄(PPdia. $5 \mathrm{~mm}$ ) $2 \mathrm{~m}$ 를 연결하고 아릿 줄의 끝에 통발 100 개를 부착한 것을 1 조의 어구로 하였으 며각 어획시험 별로 1 조의 어구를 사용 하였 다.
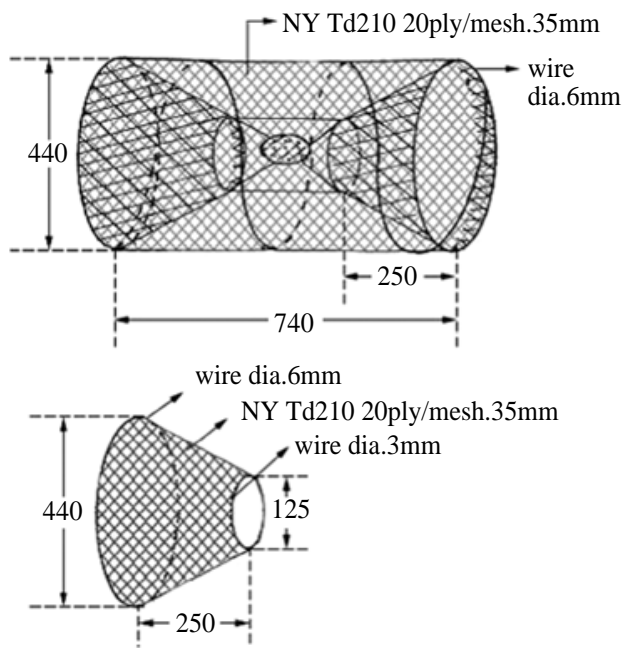

Fig. 1. Detail specification of experimental shrimp trap. 


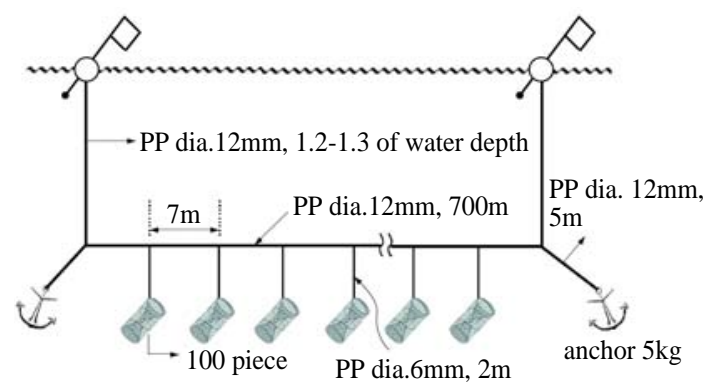

Fig. 2. Arrangement of experimental trap.

시험 및 분석 방법

시험조입은 2006년 9 월 과 2007년 8월에 각각 1 회 수행하었으며 각 시험은 침지시간별로 어구 1 조씩 총 3 조를 투 · 양망하였다. 상세한 시험 일 자별 시험시각과 위치를 Table 1 에 나타네었다. Table 1 에서 2006년 시혐은 시험코드 1 번 을 2007 년 시험은 시험코드 2 번을 부여하였고 침지시간 은 현지의 조입패턴에 따라 21시간, 43 시간, 66 시간으로 구별하여 시혐코드 A, B, C를 부여하 였다. 이와 같은 침지시간은 투망 후 1 일, 2 일, 3 일 후에 양망하는 것으로 볼 수있다. 시험에 사 용한 선 박은 4.46 톤급 민간조업선(에 덴호)을 사 용하었으며 시험해 역은 Fig. 3 에 나타넨 바와 같 이 강원도 고성군 죽왕면 오호리항에서 북동 방 향으로 약 10 마일이내의 해역이며, 수심은 약 $400 \mathrm{~m}$ 내외이고 어구는 등심선을 따라 부설하였
다. 또한 침지시간이 서로 다른 어구를 너무 가 까이 부설하면 어구가 서로 엉킬 우려가 있으므 로 약 $50-100 \mathrm{~m}$ 의 간격으로 최 대한 가까이 부설 하였다. 조업방법은 어장에 도착하여 냉동 정어 리 약 $120 \mathrm{~g}$ 을 넣은 미끼통을 통발 속에 단 후, 우 현 뒤쪽에서 모릿줄에 통발을 매 달아가면서 투 망하고, 양망은 갑판 우현에 설치된 양승기를이 용하여 모릿줄을 양승하면서 통발을 수납하며 어획물은 어종별로 분류하여 수납하였다. 어구 1 조당 투 망시간은 6 분, 양망시간은 1 시긴 40 분이 소요되었다.

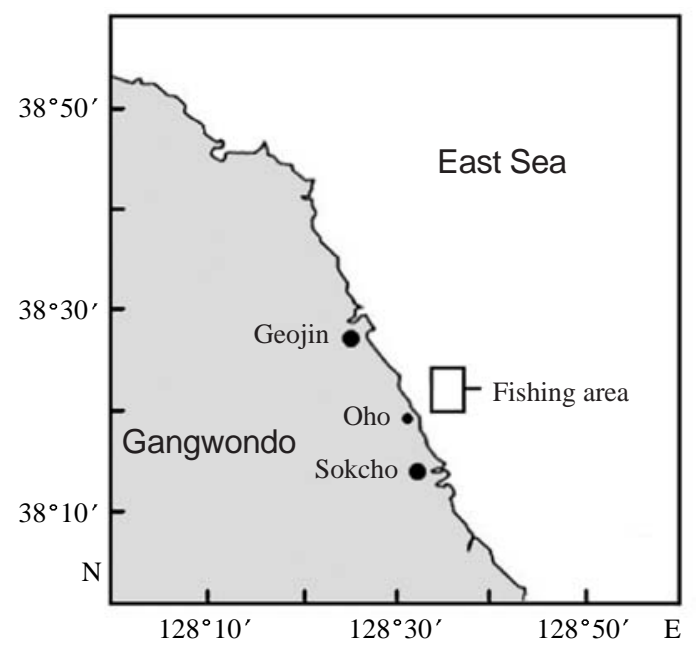

Fig. 3. Experimental fishing position in the East Sea of Korea.

Table 1. Experimental fishing time and detail position

\begin{tabular}{|c|c|c|c|c|}
\hline Code number & $\begin{array}{c}\text { Time of } \\
\text { casting and lifting }\end{array}$ & \multicolumn{2}{|c|}{$\begin{array}{l}\text { Position of casting and lifting } \\
\text { (Center of main line) }\end{array}$} & Submerged hours(hr) \\
\hline $1 \mathrm{~A}$ & $\begin{array}{l}\text { 2006.9.21 AM 12:00 } \\
\text { 2006.9.22 AM 09:00 }\end{array}$ & $38^{\circ} 20.45^{\prime} \mathrm{N}$ & $128^{\circ} 34.80^{\prime} \mathrm{E}$ & 21 \\
\hline 1B & $\begin{array}{l}\text { 2006.9.26 AM 12:30 } \\
\text { 2006.9.28 AM 07:30 }\end{array}$ & $38^{\circ} 20.45^{\prime} \mathrm{N}$ & $128^{\circ} 34.80^{\prime} \mathrm{E}$ & 43 \\
\hline $1 \mathrm{C}$ & $\begin{array}{l}\text { 2006.9.26 AM 15:00 } \\
\text { 2006.9.29 AM 09:00 }\end{array}$ & $38^{\circ} 20.50^{\prime} \mathrm{N}$ & $128^{\circ} 34.85^{\prime} \mathrm{E}$ & 66 \\
\hline $2 \mathrm{~A}$ & $\begin{array}{l}\text { 2007.8.21 AM 11:30 } \\
\text { 2007.8.22 AM 08:30 }\end{array}$ & $38^{\circ} 20.45^{\prime} \mathrm{N}$ & $128^{\circ} 34.80^{\prime} \mathrm{E}$ & 21 \\
\hline $2 \mathrm{~B}$ & $\begin{array}{l}\text { 2007.8.21 AM 12:00 } \\
\text { 2007.8.23 AM 07:00 }\end{array}$ & $38^{\circ} 20.38^{\prime} \mathrm{N}$ & $128^{\circ} 34.75^{\prime} \mathrm{E}$ & 43 \\
\hline $2 \mathrm{C}$ & $\begin{array}{l}\text { 2007.8.21 AM 14:30 } \\
\text { 2007.8.24 AM 08:30 }\end{array}$ & $38^{\circ} 20.50^{\prime} \mathrm{N}$ & $128^{\circ} 34.85^{\prime} \mathrm{E}$ & 66 \\
\hline
\end{tabular}


자료의 수집은 어획된 새우에 대하여 두 흥갑 장 및 체 중을 조사하였는데 두 흥갑장은 버니어 캘리펴 스(CD - 20CP, Mitutoyo Co.)를 이용하여 $0.01 \mathrm{~mm}$ 단위로, 체중은 정 밀저울 $\mathrm{HS} 2100 \mathrm{~A}$, Hansung Ace Co.)을 이용하여 0.1g단위로 측정 하였다. 측정된 자료를 이용하여 침지시간에 따 른 어획종별 어획량 및 어종별 크기 조성을 분석 하였다. 한편, 2007 년 도 시험에서 침지시간 43 시 간 후 양망한 어구가 양망 시 일부가 유실되어 정 상적으로 양망된 통발 56 개에서 어획된 자료 를 사용하었으며 다른 시험의 결 과와 비교할 때 에는 통 발 100 개 에 해 당하는 어 획 량으로 환산하 여 비교 분석하었다. 또한 동해안 새우 통 발어 업 이 주로 북쪽분홍새우(Pandalus eous)를 대상으 로 이루어지고 있고 본 연구의 시험어획 결 과도 북쪽분홍새우의 어획이 대부분을 차지하고 있 으므로 북쪽분 홍새 우를 중심으로 분석하였다.

\section{결과 및 고찰}

어획종 및 어획량

침지시간이 서로 다른 새우 통발의 시험코드
별 어 획량을 Table 2 에 나타내었다. Table 2 에 서 와 같이 시험코드 $2 \mathrm{~B}$ 의 양망에서 통발 44 개가 손상되어 다른 시험에서 양망한 통발의 개수와 다르므로 비교를 융이하게 하기 위해 통발 100 개가 정상적으로 양망되었을 때의 어획 량을 환 산하여 *, 표시와 함께 나타내었 다. 시험 코드 A 에서는 북쪽분홍새우만 어획되었고 $\mathrm{B}$ 와 $\mathrm{C}$ 에서 는 도화새우(Pandalus hypsinotus) 가 소량 어획 되 었으며 2C 에서 는 물렁 가시 붉은새 우(Pandalopsis japonica)가 2 마리 어 획되 었다.

시험별 어획량은 시험코드 $1 \mathrm{~A}, 1 \mathrm{~B}, 1 \mathrm{C}$ 순으로 각각 2,166.8g(261 마리), 2,950.5g(322 마리), $2,847.5 \mathrm{~g}(296$ 마리 $)$ 이 었고 이 중 북쪽분 홍새우가 각각 2,166.8g(261 마리), 2,812.2g(299 마리), $2,780.2 \mathrm{~g}(283$ 마리 $)$ 이 어 획되어 $97.42 \%$ 를 차지하 며 시험 $1 \mathrm{~B}, 1 \mathrm{C}$ 에서 도화새 우가 각각 $138.3 \mathrm{~g}(23$ 마리), $67.3 \mathrm{~g}(13$ 마리)이 어획되어 $2.58 \%$ 를 차지 하었다. 시험 $2 \mathrm{~A}, 2 \mathrm{~B}, 2 \mathrm{C}$ 에서는 각각 $2,544.1 \mathrm{~g}$ (300마리), 1,844.2g(209마리), 3,335.5g(350마리) 이 었고 이 중 북쪽분 홍새 우가 각각 2,544.1g(300 마리), 1,632.6g(174마리), 3,184.2g(324 마리)이

Table 2. Comparison of catches and species rate

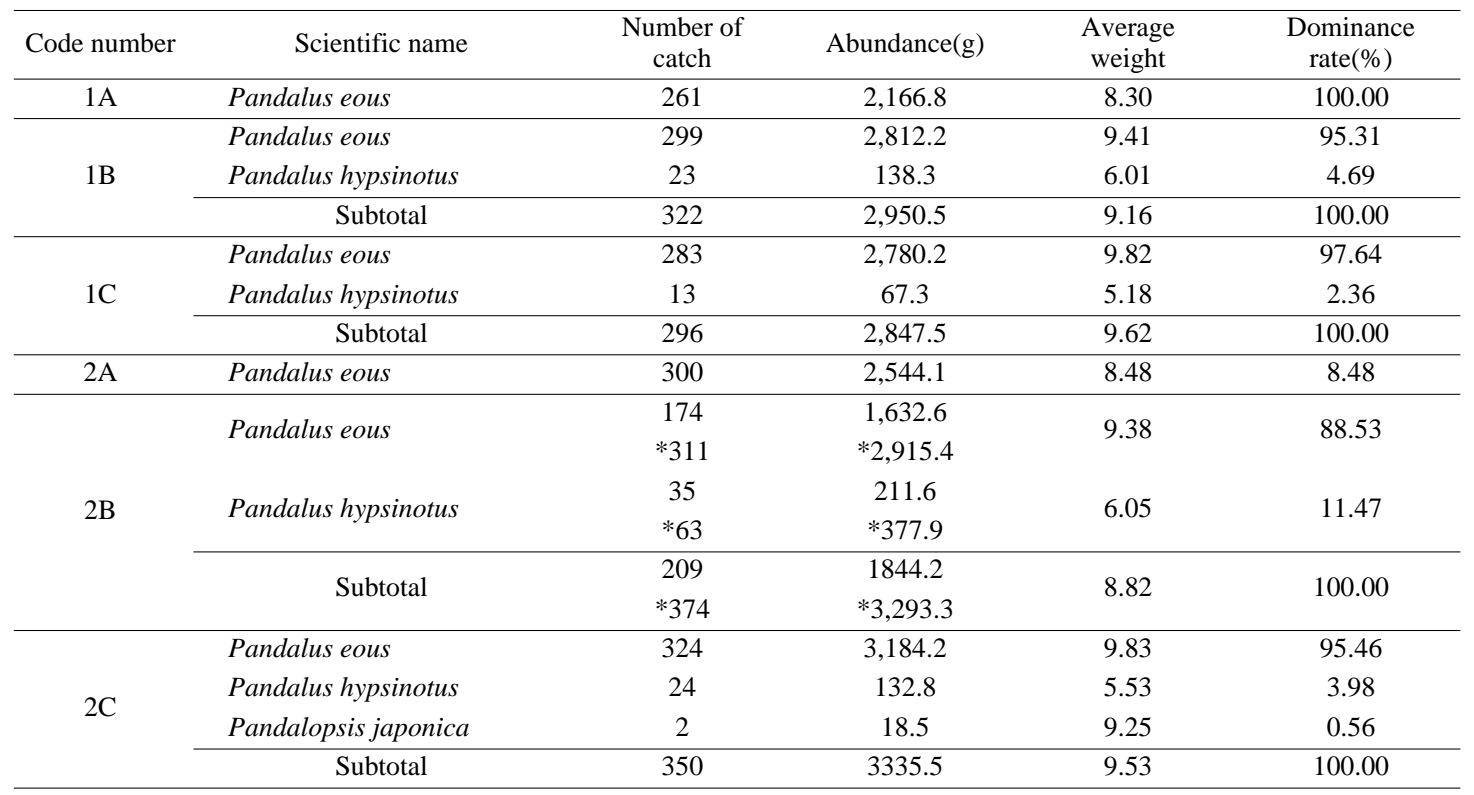

* numerical value changed to catch of 100 traps 
어 획되 어 $95.30 \%$ 로 대부분 을 차지하며 시험 $2 \mathrm{~B}$, 2C에 서 도화새 우가 각각 211.6g(35 마리), $132.8 \mathrm{~g}$ (24마리)이 어획되어 $2.74 \%$ 를 차지하였다. 또한 시험 2C에서 물 렁가시붉 은새 우가 $18.8 \mathrm{~g}$ (2마리) 이 어획되어 $1.96 \%$ 를 차지하였다.

이것을 통발 1 개의 어획량으로 보면 시험코드 $1 \mathrm{~A}, 1 \mathrm{~B}, 1 \mathrm{C}$ 순으로 각각21.67g, 29.51g, 28.48g 이 었고 이중 북쪽분홍새 우가 각각 $21.67 \mathrm{~g}, 28.12 \mathrm{~g}$, $27.80 \mathrm{~g}$ 이 어획되었다. 또 $2 \mathrm{~A}, 2 \mathrm{~B}, 2 \mathrm{C}$ 시험에서는 각각 $25.44 \mathrm{~g}, 32.93 \mathrm{~g}, 33.36 \mathrm{~g}$ 이었고 이중 북쪽분 홍새우가 각각 $25.44 \mathrm{~g}, 29.15 \mathrm{~g}, 31.84 \mathrm{~g}$ 이 어획되 었다. 따라서 침지시간이 약 1 일에서 약 2 일로 증가됨에 따라 어획량은 2006 년, 2007 년 시험에 서 각각 $26.57 \%, 22.75 \%$ 증가한 것으로 나타나 큰 차이가 나타났으며 침지시간이 약 2 일에서 3 일로 증가되었을 때는 각각 $-3.49 \%, 1.29 \%$ 감 소 또는 증가한 것으로 나타나 큰 차이가 없는 것으로 나타났다. 또한 북쪽분홍새 우의 침지시 간에 따른 어획량 증감을 보더라도, 침지시간이 약 1 일에서 약 2 일로 증가됨에 따라 어획 량은 2006년, 2007년 시험에 서 각각 22.94\%, 12.73\% 증가한 것으로 나타나 큰 차이가 나타났으며 침 지시간이 약 2 일에서 3 일로 증가되었을 때는 각 각 $-1.14 \%, 8.44 \%$ 감소 또는 증가한 것으로 나 타나 2007년 시험에서 다소 큰 차이가 있었으나 전체적으로는 유사한 경 향으로 나타났다.

\section{두흉갑장 및 체중 분포}

2006 년 시험에서 어획된 북쪽분홍새우의 두 흥갑장 및 체 중 분포를 Fig. 4 에, 2007년 시험의 결 과는 Fig. 5 에 나타내었다. 2006년 시험에서 어획된 북쪽분홍새우의 평균 두흥갑장은 시험 코드 $1 \mathrm{~A}, 1 \mathrm{~B}, 1 \mathrm{C}$ 시험 순으로 각각 $23.77 \mathrm{~mm}$, $25.00 \mathrm{~mm}, 25.57 \mathrm{~mm}$ 로 나타나 침지시간이 길수 록 소형 개체의 어획은 줄어들고 비교적 큰 개체 의 어획은 늘어나는 것으로 나타났다. 또한침지 시간이 증가함에 따라 두흥갑장 $20 \mathrm{~mm}$ 이하 소 형 새우가 차지하는 비 율도 각각 $15.33 \%, 1.34 \%$,
$0.35 \%$ 와 같이 점점 큰 폭으로 작아지는 것으로 나타나 침지시간이 길수록 소형 개체의 어획은 줄어드는 것으로 나타났다. 이러한 결 과는 통발 의 침지시간이 늘어나면서 미끼의 효과가 떨어 짐에 따라 상대적으로 통발을 쉽게 빠져나잘 수 있는 소형 새우가 통발 밖으로 빠져나간 것으로 판단된 다. 2007 년 시험에서도 시험코드 $2 \mathrm{~A}, 2 \mathrm{~B}$, 2C 시험 순으로 각각 $23.83 \mathrm{~mm}, 24.95 \mathrm{~mm}$, $25.45 \mathrm{~mm}$ 로 유사한 결과가 나타나 침지시간이 길수록 소형 개체의 어획은 줄어들고 비고적 큰 개체의 어획은 늘어나는 것으로 나타났다. 또한 침지시간이 증가함에 따라 두 흥갑장 $20 \mathrm{~mm}$ 이 하 소형 새우가 차지하는 비율도 각각 $15.33 \%$, $2.30 \%, 0.31 \%$ 와 같이 점 점 큰 폭으로 작아지는 것으로 나타나 2006년 도 시험과 유사한 결 과를 나타내었다. 따라서 그림에서 보여주는 그래프 의 경향으로 보아, 주 대상종인 북쪽분 홍새 우의 어획마리수와 어획량이 모두 증가함에 따라 평 균중량도 증가하였으며 침지시간이 경 과할수록 큰 개체는 통발 속에 남아있고 소형 개체는 통발 밖으로 빠져나간다는 것을 명확히 알 수 있었다.

\section{침지시간에 따른 어획량 및 평균체중}

2006년, 2007년 시험을 종합하여 침지시간에 따른 어획량과 새 우의 평 균체 중의 변화를 Fig. 6 에 나타내었다. 어획된 모든 새우의 어획량 변화 를 살펴보면 새우의 어획량은 침지시간에 따른 $\mathrm{A}, \mathrm{B}, \mathrm{C}$ 시험 순으로 각각 $4.71 \mathrm{~kg}, 6.24 \mathrm{~kg}, 6.18 \mathrm{~kg}$ 으로 나타났으며, 그 중 북쪽분 홍새 우의 어획량 은 각각 $4.71 \mathrm{~kg}, 5.73 \mathrm{~kg}, 5.96 \mathrm{~kg}$ 으로 나타났다. 또 한 어획된 모든 새우 1 마리당 평균체 중의 변화 를 살펴보면 새우의 평균체 중은 침지시간에 따 른 $\mathrm{A}, \mathrm{B}, \mathrm{C}$ 시험 순으로 각각 $8.40 \mathrm{~g}, 8.97 \mathrm{~g}, 9.57 \mathrm{~g}$ 으로 나타났으며, 그 중 북쪽분홍새 우의 평 균체 중은 각각 $8.40 \mathrm{~g}, 9.39 \mathrm{~g}, 9.83 \mathrm{~g}$ 으로 나타났다. 그 리고 주 대상어종인 북쪽분 홍새 우의 경 우, 어획 마리수를 보면 C 시험의 경우가 B 시험의 경우 보다 다소 적어졌으나 어획량은 오히려 다소 증 

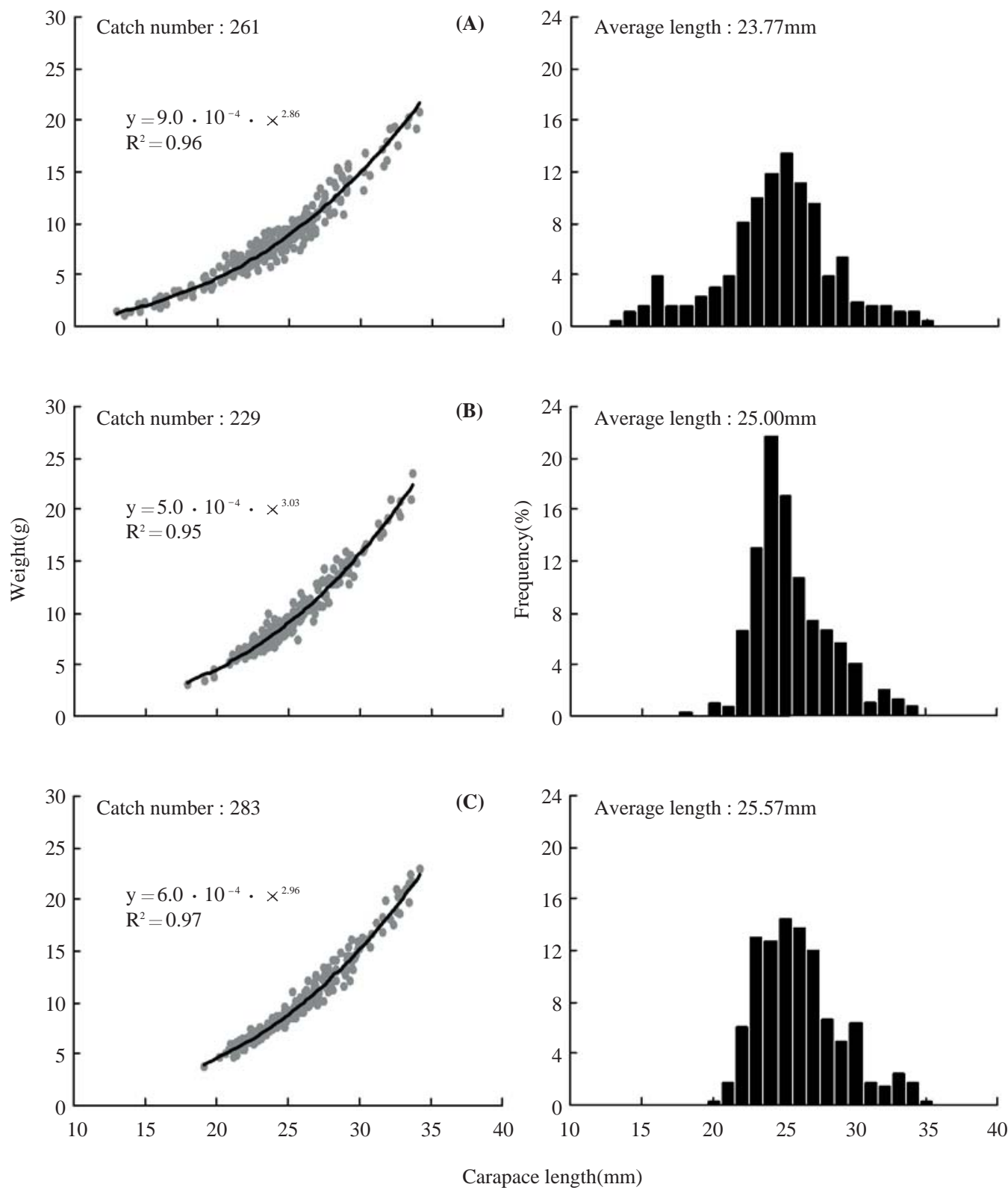

Fig. 4. Distribution of carapace length and weight of Pandalus eous in 2006. (A) 21hours submerged, (B) 43hours submerged, (C) 66hours submerged.

가한 것으로 나타났다. 이것은 침지시간이 지남 에 따라 새우의 통발속으로의 유입은 일부 지속 되면서 소형 새우는 빠져나간 것으로 판단할 수 있다.

Fig. 5 에서 나타난 결 과를 종합하면 총 어획
량은 침지시간 약 2 일 에서 가장 많았고 침지시 간 약 3 일에서 다소 감소하였으나 주 대상어종 인 북쪽분 홍새 우는 오히려 증가한 것으로 나타 나 침지시간 약 2 일 또는 약 3 일이 적당한 양망 시점으로 나타났다. 그러나 새우 1 마리당 평균 

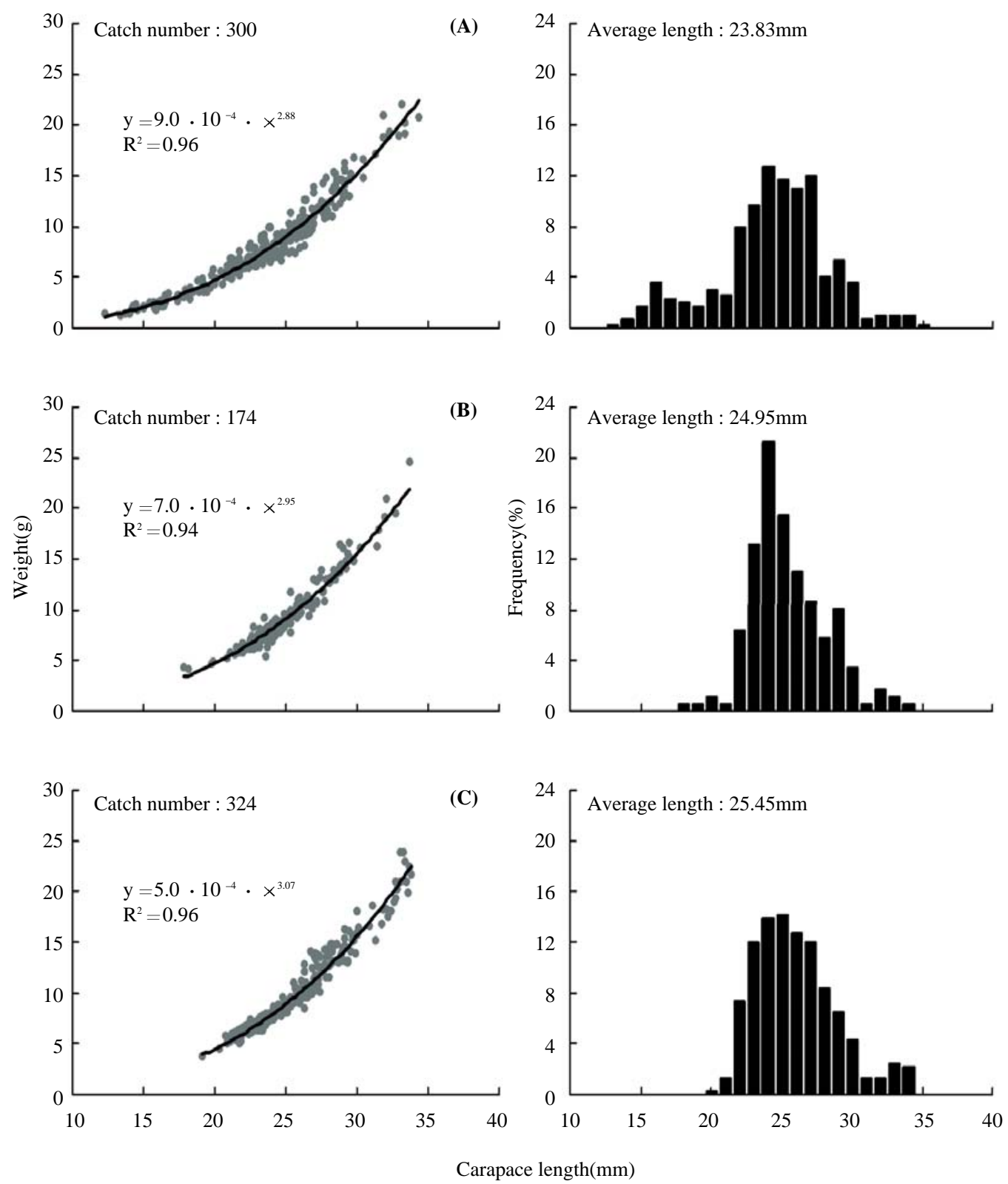

Fig. 5. Distribution of carapace length and weight of Pandalus eous in 2007. (A) 21hours submerged, (B) 43hours submerged, (C) 66hours submerged.

체중은 북쪽분홍새 우나 기타 새우도 모두 증가 하고 있는 것으로 나타나 본 결 과만으로는 침지 시간 약 3 일이 가장 적당한 양망시 점으로 나타 났다.

\section{고 찰}

본 연구의 대상이 된 통발어업은 북쪽분 홍새 우를 주 대상으로 하고 있다. 어획시험에서 다량 의 도화새우와 물렁가시붉은새 우가 2 마리 어 획 되었으나 도화새우는 크기가 작으므로 소득원 


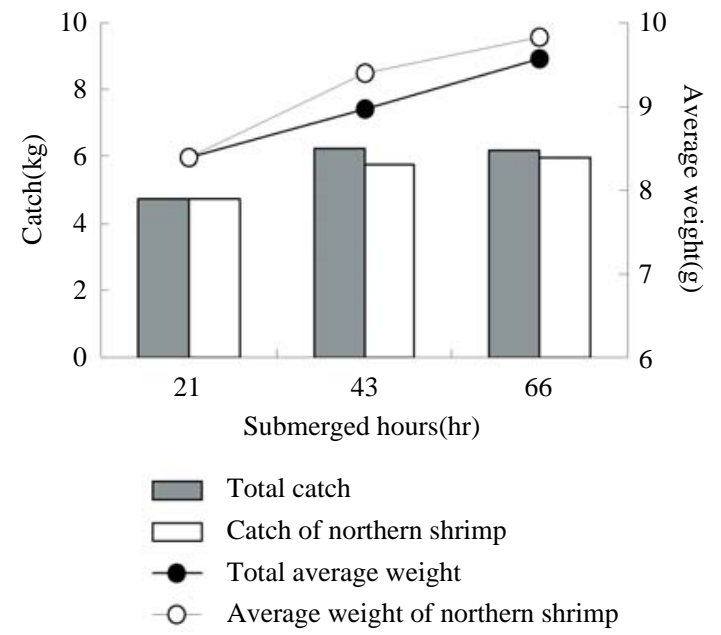

Fig. 6. Variation of catches and shrimp's average weight by submerged hours.

으로서 가치가 거의 없으며 물렁가시붉은새우 는 어획이 미 미하였다. 따라서 본 연 구의 결 과에 서는 북쪽분홍새우의 침지시간에 따른 어획변 화가 중요할 것이다. 위에서 나타난 결 과를 보면 시험어장에서 북쪽분홍새우를 주 대상으로 하 는 통발은 투망 후 적어도 2 일 이상의 침지시간 이 경 과한 후 양망하는 것이 여러 가지 면에서 호율적이다. 어획량 측면에서 보면 투망 후 3일 째가 양망시 점으로 좋은 것으로 생각할 수 있으. 나, 어구의 침지시간이 길어질수록 기상변회, 타 어구와의 조우 등에 의한 어 구사고가 발생할 수 있고 미끼의 효과도 떨어지며 어획물의 상태가 나빠질 가능성이 크기 때문에 이러한 점을 종합 적으로 고려하면, 투망 후2일이지난 후가 양망 시점으로 적합하다고 퐌단된다. 실제로 시험어 장에 있어서 어업인들은 투망 후 2 일이 지난 후 양망하고 있으며 기상이 여 의치 않을 때 그 다음 날에 양망하고 있다. 이겻은 아마도 오랜 경험을 통하여 어업인 스스로 적 정 양망시점을 터 득한 것 으로 생 각된 다(Shimamura and Soeda, 1979).

본 시험결 과에서 도화새 우는 침지시간 약 1 일 이 지 난 통발에서는 전혀 어획되지 않았고 침지 시간 약 2 일이 지난 후부터 어획되었기 때문에
도화새우가 미끼의 냄새를 인지하고 통발에 접 근하는 시간이 북쪽분홍새우보다 많이 소요된 다는 분석도 해볼 수 있겠으나, 두 차례의 시혐 결 과이므로 현 재로서 쉽 게 판단할 수 없다.

Fig. 5 에서 전체 새우의 평균체중과 북쪽분홍 새우의 평균체중의 차이가 침지시간 약 2 일이 지난 어획에서 가장 크고 침지시간 약 3 일이 지 난 어획에서 다시 작아진 것은, 통 발에 입 망되었 던 개체 가운데 크기가 작은 도화새 우가 침지시 간의 경 과로 미끼의 호과가 떨어짐에 따라 쉽 게 빠져나간것으로 분석된다. 그러나 통발속에 입 망된 새우사이에 공간을 점유하기 위한 상호작 웅이 있을 수 있으며 이에 따라 상대적으로 크기 가 작은 도화새 우가 통 발에서 많이 빠져나갔을 가능성도 있다.

본 시험에서 침지시간을 더욱 세 분하여 매시 간 또는 몇 시간마다 분석할 수도 있겠으나 만약 그러한 시험을 설 계하여 수행할 경우, 사용하는 통발의 수를 시간대별로 나누면 시험별 어획량 이 작아 결과의 정도가 떨어질 것이며, 통발의 수를 늘이면 어구의 부설위치 차이가 커지므로 어획자료를 신뢰할 수없을 것으로 판단된 다. 따 라서 실제 어업에서는 어업인 의 생 할패턴, 위판 시간 등을 고려하여 1 일 단위로 매 정해진 시간 에 투 · 양망작업을 하므로 본 연구결 과의 활용 측면에서 1 일 단위의 시험을설 계하였다.

본 연 구는 동해안에서 가장 보편적으로 사용 되고 있는 새 우 통발을 대상으로 하였으며 각 해 역 별로 많이 사용되는 어 구를 우선 대상으로 하 여, 적정 어 구사용량 및 투 - 양망 시점의 결 정과 같은 어 구운용에 도움이 될 수 있는 후속 연구가 많이 수행되 어야 할 것 으로 생각된 다.

\section{결 론}

동해안에서 주로 사용되고 있는 스프링식 장 구형 새 우통발을 이용하여 침지시간에 따른 어 획 량의 변화를 알아보기 위하여 강원도 고성군 오호리항 연 안에서 어획시험을 실시하였다. 침 
지시간 21 시간의 통발에서는 북쪽분홍새우만 어획되었고 침지시간 43시간, 66 시간의 통발에 서는 도화새 우 소량과 물렁가시붉은새우 2 마리 가 어획되었다. 시험별 통발 1 개의 어획량은 시 험코드 $1 \mathrm{~A}, 1 \mathrm{~B}, 1 \mathrm{C}$ 순으로 각각 $21.67 \mathrm{~g}, 29.51 \mathrm{~g}$, $28.48 \mathrm{~g}$ 이었고 이중 북쪽분 홍새 우가 각각21.67g, $28.12 \mathrm{~g}, 27.80 \mathrm{~g}$ 이 어획되었다. 또 $2 \mathrm{~A}, 2 \mathrm{~B}, 2 \mathrm{C}$ 시 험에서 는 각각 $25.44 \mathrm{~g}, 32.93 \mathrm{~g}, 33.36 \mathrm{~g}$ 이 었고 이 중 북쪽분홍새 우가 각각 $25.44 \mathrm{~g}, 29.15 \mathrm{~g}, 31.84 \mathrm{~g}$ 이 어획되었다. 따라서 침지시간이 약 1 일에서 약 2 일로 증가됨에 따라 어획량은 약 $24.66 \%$ 증 가한 것으로, 침지시간이 약 2 일 에서 3 일 로 증가 되었을 때는 $-1.1 \%$ 로 차이가 없는것으로 나타 났다. 2006년 시험에서 어획된 북쪽분홍새우의 평균 두흥갑장은 시험코드 $1 \mathrm{~A}, 1 \mathrm{~B}, 1 \mathrm{C}$ 시험 순 으로 각각 $23.77 \mathrm{~mm}, 25.00 \mathrm{~mm}, 25.57 \mathrm{~mm}$ 로, 2007 년 은 각각 $23.83 \mathrm{~mm}, 24.95 \mathrm{~mm}, 25.45 \mathrm{~mm}$ 로 나타 나 침지시간이 길수록 소형 개체의 어획은 줄어 들고 비교적 큰 개체의 어획은 늘어나는 것으로 나타났다. 시험에서 어획된 모든 새우의 어획량 은 침지시간에 따른 $\mathrm{A}, \mathrm{B}, \mathrm{C}$ 시험 순으로 각각 $4.71 \mathrm{~kg}, 6.24 \mathrm{~kg}, 6.18 \mathrm{~kg}$ 으로 나타났으며, 그 중 북 쪽분홍새우의 어획 량은 각각 $4.71 \mathrm{~kg}, 5.73 \mathrm{~kg}$, $5.96 \mathrm{~kg}$ 으로 나타났다. 또한 새우 1 마리당 평균체 중은 각각 $8.40 \mathrm{~g}, 8.97 \mathrm{~g}, 9.57 \mathrm{~g}$ 으로 나타났으며, 그 중 북쪽분홍새우의 평균체 중은 각각 $8.40 \mathrm{~g}$, $9.39 \mathrm{~g}, 9.83 \mathrm{~g}$ 으로 나타났다. 결론적으로 실제 어 업에서는 어구를 2 일 또는 3 일 동안 침지해 놓아 도 침지시간동안 조업을 하지 않는 것이 아니라 여러 개의 어구를 운용하면서 매일 조업하므로, 시험어장에서 북쪽분홍새우를 주 대상으로 하 는 통발은 투망 후 적어도 2 일 이상의 침지시간 이 경 과한 후 양망하는 것이 효율적이며 어획량 측면에서 보면 투망 후 3 일째가 앙망 시점으로 좋은 것으로 나타났다. 그러나 어 구의 침지시간 이 길어질수록 기상변화, 타 어구와의 조우 등에 의한 어구사고가 발생할 수 있고 미끼의 효과도 떨어지며 어획물의 상태가 나빠질 가능성이 크
기 때문에 이 러한 점을 종합적으로 고려하면, 투 망 후 2일이 지난 후가 양망시 점으로 적합하다 고 판단된 다.

$$
\text { 사 사 }
$$

이 연 구는 국립수산과학원(생분해성 수산자 재 응용기 술 개 발, RP - $2009-\mathrm{FE}-012)$ 의 지 원 에 의해 수행되었습니다.

\section{참고문헌}

An, Y.I. and J.Y. Park, 2005. Octopus fisheries in the coastal waters of Gangneung - I - Pot fishery - . J. Kor. Soc. Fish. Tech., 41(4), 276 - 277.

An, Y.I. and J.Y. Park, 2006. Octopus fisheries in the coastal waters of Gangneung - II -Octopus drift line fishery -. J. Kor. Soc. Fish. Tech., 42(2), 84 85.

Chang, H.Y., J.G. Koo, K.W. Lee, B.K. Cho and B.G. Jeong, 2008a. Fluorescent characteristics of baits and bait cages for swimming crab Portunus trituberculatus pots. J. Kor. Soc. Fish. Tech., 44(3), $177-182$

Chang, H.Y., J.G. Koo, K.W. Lee, B.K. Cho and B.G. Jeong, 2008b. Attracting effect of baits used the byproduction for swimming crab Portunus trituberculatus pots. J. Kor. Soc. Fish. Tech., 44(4), 287 290.

Chen, C.T., K.C. Yu, K.Y. Hsieh and C.H. Ho, 1998. The Mathematical Catch Model of Pots for Yellow Sea Bream. J. Fish. Soc. Taiwan, 25(2), $93-100$.

Egger, D.M., 1982. A Methodology for Estimating Area Fished for Baited Hooks and Traps Along a Ground Line. CAN. J. FISH. AQUAT. SCI., 39, 448 -453.

Honda, N. and K. Fujita, 2005. Selective fishing of smallmouth bass, Micropterus dolomieu by soaking time zone of gillnet. Nippon Suisan Gakkaishi, 71(1), $60-67$.

Jeong, S.B., J.H. Lee, H.S. Kim, B.G. Kwon, D.K. Ah and Y.B. Cho, 2002. Relationship between soak time and catch numbers of plastic pot for sea-eel, 
Conger myriaster. Bull. Kor. Soc. Fish. Tech., 38(3), $202-207$.

Kim, B.Y., Y.S. Park and C.H. Lee, 2009. Hooking rate and bait loss rate of traditional hairtail hand line according to immersion time in the coastal waters of Jeju. J. Kor. Soc. Fish. Tech., 45(2), 81 -82.

Ogura, M., T. Arimoto and Y. Inoue, 1980. Influence of the immersion time on the hooking rate of a small bottom long-line in coastal waters. Bulletin of the society of scientific fisheries. 46(8), 963 -966.

Shimamura, T. and H. Soeda, 1979. The change of catch of tuna longtime depends on soaking time and soaking time zone of gear. Bulletin of the society of scientific fisheries, 45(9), $1981-1085$.

2009년 9월6일 접수

2009년 10 월 29 일 1 차 수정

2009년 10 월 30 일 수리 